\title{
Effects of Highly Active Antiretroviral Therapy (HAART) on some Serum Micronutrients and Electrolytes Levels in HIV Infected Patients in Southern Nigeria
}

\author{
Digban Awharentomah Kester ${ }^{1}$, Okogun Godwin Ray ${ }^{2}$, Enitan Seyi Samson ${ }^{3 *}$ and Eruotor Ogheneochuko Harrison ${ }^{2}$ \\ ${ }^{1}$ Department of Medical Laboratory Science, Igbinedion University Okada, Nigeria
}

${ }^{2}$ Department of Medical Laboratory Service, Ambrose Alli University, Ekpoma, Nigeria

${ }^{3}$ Department of Medical Laboratory Science, Babcock University, Ilishan-Remo, Nigeria

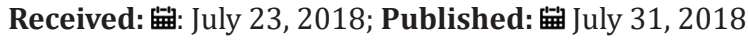

*Corresponding author: Enitan Seyi Samson, Department of Medical Laboratory Science, Babcock University, Ilishan-Remo, Nigeria

\begin{abstract}
Micronutrients and electrolytes deficiencies are prevalent among HIV-infected populations. The use of Highly Active Antiretroviral Therapy (HAART) on the other hand has been shown to increase the life expectancy of HIV infected individuals. The present study was designed to determine the effects of HAART on some serum micronutrients and electrolytes concentrations in HIV positive patients attending Emuoha General Hospital, Emuoha Local Government Area, River State, Southern Nigeria, six months post-therapy. A cohort of 163 patients comprising 111 HIV Positive subjects ( 25 males and 86 females) and 52 apparently healthy HIV negative controls (11 males and 41 females) were recruited for this study. HIV infection was detected using rapid tests Kits: Alere DetermineTM HIV-1/2 Ag/Ab Combo Rapid Tests Kits (Abbot Rapid Diagnostics, California, USA), Uni-GoldTM Recombigen ${ }^{\circledR}$ HIV-1/2 (Trinity Biotech Plc, Wicklow, Ireland) and Chembio HIV 1/2 STAT-PAK® Rapid Test Kit (Chembio Diagnostic systems, New York, USA). The serum micronutrients and electrolytes levels of the patients were analyzed at diagnosis and 6 months after initiation of HAART using atomic absorption spectrophotometry and ion selective electrode automation, respectively. The outcome of this study show that the mean \pm SD HAART serum Vitamin A $(8.02 \pm 0.70 \mu \mathrm{g} / \mathrm{dl})$, Vitamin C $(1.21 \pm 0.42 \mathrm{mg} / \mathrm{dl})$, Vitamin E $(0.41 \pm 0.02 \mathrm{mg} / \mathrm{dl}), \mathrm{Zinc}(89.20 \pm 4.73 \mu \mathrm{g} / \mathrm{dl}) \mathrm{and}$ Selenium $(44.42 \pm 5.23 \mu \mathrm{g} / \mathrm{dl})$ serum levels of the HIV positive Patients were lower than the controls $(9.70 \pm 0.93 \mu \mathrm{g} / \mathrm{dl}, 1.73 \pm 0.16 \mathrm{mg} / \mathrm{dl}, 0.67 \pm 0.09 \mathrm{mg} /$ $\mathrm{dl}, 98.48 \pm 3.34 \mu \mathrm{g} / \mathrm{dl}$ and $55.17 \pm 6.02 \mu \mathrm{g} / \mathrm{dl}$, respectively), but significantly higher $(\mathrm{P}<0.05)$ than the mean \pm SD Pre-HAART values $(6.32 \pm 1.11 \mu \mathrm{g} / \mathrm{dl}$, $0.75 \pm 0.09 \mathrm{mg} / \mathrm{dl}, 0.35 \pm 0.04 \mathrm{mg} / \mathrm{dl}, 76.20 \pm 9.16 \mu \mathrm{g} / \mathrm{dl}$ and $23.30 \pm 5.91 \mu \mathrm{g} / \mathrm{dl}$, respectively). On the other hand, the mean \pm SD serum copper levels of the HAART HIV-positive subjects $(31.66 \pm 2.33 \mu \mathrm{g} / \mathrm{dl})$ were higher than the controls $(26.43 \pm 3.34 \mu \mathrm{g} / \mathrm{dl})$, but significantly lower $(\mathrm{P}<0.05)$ than that of the pre-HAART $(35.12 \pm 2.82 \mu \mathrm{g} / \mathrm{dl})$. Furthermore, the results also show that the mean \pm SD HAART serum Potassium $(3.92 \pm 0.43 \mathrm{mmol} / \mathrm{L})$ and Sodium $(134.50 \pm 3.27 \mathrm{mmol} / \mathrm{L})$ serum levels of the HIV positive Patients were lower than the controls $(4.07 \pm 0.57 \mathrm{mmol} / \mathrm{L}$ and $137.46 \pm 3.35 \mathrm{mmol} / \mathrm{L}$, respectively), but significantly higher $(\mathrm{P}<0.05)$ than the mean \pm SD Pre-HAART values $(3.29 \pm 0.33 \mathrm{mmol} / \mathrm{L}$ and $132.61 \pm 2.46 \mathrm{mmol} / \mathrm{L}$, respectively). Meanwhile, there was no significant difference $(\mathrm{P}>0.05)$ between the mean \pm SD Pre-HAART $(98.92 \pm 5.65 \mathrm{mmol} / \mathrm{L})$ and HAART $(99.59 \pm 6.53 \mathrm{mmol} / \mathrm{L})$ serum chloride levels of HIV-positive Patients and the Controls $(100.42 \pm 6.28 \mathrm{mmol} / \mathrm{L})$. Also, there were no significant differences between the males and females in all the parameters measured, except for serum vitamin $C$ and zinc levels. On one hand, while the HIV positive males' mean \pm SD HAART vitamin C serum level $(1.46 \pm 0.36 \mathrm{mg} / \mathrm{dl})$ was significantly higher $(\mathrm{P}<0.05)$ than that of their female counterparts $(1.14 \pm 0.41 \mathrm{mg} / \mathrm{dl})$, on the other hand, their mean \pm SD HAART serum zinc level $(89.42 \pm 2.45 \mu \mathrm{g} / \mathrm{dl})$ was significantly lower than that of the females $(94.71 \pm 4.71 \mu \mathrm{g} / \mathrm{dl})$. This study confirms that micronutrients and electrolytes deficiencies exist in HIV infection and further strengthened the earlier claim about the efficacy of HAART in improving life expectancy through repletion of serum micronutrients and electrolytes levels in HIV infection.
\end{abstract}

Keywords: HIV; AIDS; HAART; Micronutrients; Vitamins; Minerals; Electrolytes; Serum levels

Abbreviations: HIV: Human Immunodeficiency Virus; AIDS: Acquired Immunodeficiency Syndrome; HAART: Highly Active Antiretroviral Therapy; ROS: Reactive oxygen species; RPM: Revolution per minute; $\mathrm{Na}+$ : Sodium; $\mathrm{K}+$ : Potassium; $\mathrm{Cl}$-: Chloride; $\mathrm{HCo}_{3}$ - : Bicarbonate

\section{Introduction}

One of the greatest challenges of the 21st Century is the Human Immunodeficiency Virus (HIV), the causative agent of the Acquired Immunodeficiency Syndrome (AIDS), [1,2]. As at 2015, about 36.7 million people were living with HIV/AIDS globally, with an estimated 25.5 million infected people in Sub-Saharan
African [3]. The introduction and use of antiretroviral therapies (ART) has revolutionized the management and treatment of HIV/ AIDS globally resulting in increased life expectancy [4-8]. Current treatment guidelines by WHO recommend the use of a combination of at least 3 ARV drugs which include: 2 Nucleoside Reverse Transcriptase Inhibitors (NRTIs) combined with 1 medication 
from either of the 2 remaining classes; the Non-Nucleoside Reverse Transcriptase Inhibitors (NNRTIs) or the Protease Inhibitors (PIs). When such drugs, typically three or four, are taken in combination, the approach is known as highly active antiretroviral therapy HAART. A combination of Nevirapine, Stavudine, and Lamivudine or Lamivudine with Zidovudine is frequently prescribed [8-10]. The prescription and use of a particular therapy depends on individual's tolerability, the cost, and the therapeutic objectives [11].

Research has shown that some biochemical abnormalities accompany infection with Human Immunodeficiency Virus. These changes occur as a result of the complications of the disease itself, for example the body's normal response to infection depletes nutritional stores. Furthermore, metabolic stress responses cause catabolism of protein stores. In addition, undernourishment and micronutrient deficiencies exacerbate immunosuppression, oxidative stress, acceleration of Human Immunodeficiency Virus (HIV) replication and CD4 T-Cell depletion in HIV-infected individuals [12-14].

Malnutrition is one of the major complications of HIV infection and a significant factor in the progression of the infection into full-blown AIDS [15]. Oxidative stress induced by the production of reactive oxygen species (ROS) may play a critical role in the stimulation of HIV replication and the development of Immunodeficiency [16-18]. Excessive production of ROS such as superoxide anion, hydroxyl radical, and hydrogen peroxide may be related to an increased activation of polymorphnuclear leukocytes during infections or influenced by the pro-oxidant effect of tumor necrosis factor (TNF) produced by activated macrophages during the course of HIV infection [19]. The debilitating effect of ROS can be prevented or moderated by a normal antioxidant defense largely provided by firstly the integrity of an enzymatic system that requires adequate intake of trace minerals such as selenium, copper, zinc, and manganese, and secondly adequate concentrations of vitamin $\mathrm{A}, \mathrm{C}$ and $\mathrm{E}$ and $\beta$-carotene in the cytoplasm and lipid membrane of the cells [18].

Micronutrients which comprise of essential trace elements (e.g Zinc, Copper and Selenium) and vitamins (e,g Vitamin A, C and E) are nutrients needed in minute specific quantities in the body which play leading roles in the production of enzymes, hormones and other substances, helping to regulate growth activity, essential in wound healing, development and the functioning of the immune and reproductive system, maintenance of the integrity of skin and mucous membranes, which also function as a barrier to bacteria and viruses and protection against lipid peroxidation among several others [20-23]. Most micronutrients are not generated in the body but are derived from food intake [24-26]. Deficiencies of these micronutrients may result in: fatigue, depression, and widespread abnormalities in connective tissue, such as inflamed gingivae, petechiae, perifollicular hemorrhages, impaired wound healing, coiled hairs, hyperkeratosis and bleeding into body cavities [27]. It may also lead to damage of cell membrane and leakage of cell contents to the extracellular fluid compartment, cardiac or skeletal myopathies, neuropathies, and liver necrosis, muscle and neurological problems [28,29]. Still, deficiencies of some micronutrients have been associated with impaired immunological functions $[12,30,31]$. For instance, zinc deficiency has been reported to decrease lymphocyte concentrations, copper deficiency reduced cytokine response, while selenium deficiency negatively impacted on proper functioning of the neutrophils and T-lymphocytes [3234].

Electrolytes on the other hand, are charged low molecular mass molecules present in plasma and cytosol. They are classified as either anions (negatively charged) or cations (positively charged). The major electrolytes include Sodium $(\mathrm{Na}+)$, Potassium $(\mathrm{K}+)$, Chloride (Cl-) and bicarbonate (HCo3-) and they occur primarily as free ions. Sodium is the major cation of the extra cellular fluid (ECF) and as such plays a central role in the maintenance of the normal distribution of water and osmotic pressure in various fluid compartments [35]. It regulates the total amount of water in the body and out of individual cells. Potassium on the other hand is the major intracellular cation having an average cellular concentration in tissue cells of $150 \mathrm{mmol} \mathrm{L}-1$. The proper level of potassium is essential for normal cell function. Among the many functions of potassium in the body are regulation of the heartbeat and the functions of the muscles. In addition to water balance, these electrolytes play an important role in maintenance of $\mathrm{pH}$, regulation of heart and muscle function, electron transfer reactions as well as serving as cofactors for enzymes. Chloride is the major extracellular anion and together with sodium represent the majority of the osmotically active constituents of plasma and is significantly involved in: maintenance of water distribution, osmotic pressure and anion-cation balance in ECF. Determination of body fluid concentrations of the four major electrolytes (Na+, $\mathrm{K}+, \mathrm{Cl}-$ and $\mathrm{HCo} 3$ ) is commonly referred to as an "Electrolyte Profile". Disorders of water imbalance include hyponatreamia, hypernatraemia, hypokalaemia, hyperkalaemia occur in conditions of electrolyte disturbance, such as severe malaria infection and cholera $[35,36]$.

Micronutrients and electrolytes deficiencies are prevalent in many HIV-infected populations, and have been associated with accelerated replication of HIV, depletion of CD4 T-Cell, impaired Immune responses and increased HIV disease progression to full blown acquired immunodeficiency syndrome (AIDS) in HIVinfected individuals $[30,37,38]$. Still, these deficiencies have been shown to be associated with renal impairment and dysfunction [39], more frequent opportunistic infections and a greater incidence of HIV-related mortality [40,41]. Possible mechanisms include increased intracellular oxidative stress, enhanced viral replication, and a reduction in the number of circulating CD4 lymphocytes associated with individual or accumulated nutrient deficiencies $[42,43]$. These mechanism, alone or in part, may contribute to the increased morbidity, more rapid disease progression, and the higher mortality seen in HIV-infected patients with micronutrient deficiencies [44].

Though HAART has considerably facilitated the management of HIV/AIDS where it is available, correction of micronutrients and electrolytes deficiencies is critical to clinical outcome. And since, micronutrient deficiencies may persist in the era of HAART, 
research studies designed to determine whether initiation of HAART will ameliorate micronutrients and electrolytes deficiencies or to recommend or refute the benefit of providing micronutrient supplements to HIV-positive persons receiving HAART are very important. Scarcity of information in this regard, necessitates this research. The aim of this current study is therefore to determine whether or not HAART initiation will improve serum micronutrients and electrolytes serum concentrations of HIV positive Patients attending Emuoha General Hospital, Emuoha Local Government Area, River State, Southern Nigeria, six-months post-therapy.

\section{Material and Methods}

\section{Study Area}

The study was carried out at the Emuoha General Hospital, Emuoha Local Government Area of Rivers State, Southern Nigeria co-ordinates: 4053'0" N 6052'0"E. The LGA consists of 14 political wards with an area of $831 \mathrm{~km} 2$ and a population of 201,901 as at 2006 census [45].

\section{Study Design}

The study is a prospective cross-sectional, comparative study of HIV positive Patients pre-HAART and six months after initiation of HAART. A reference group of healthy HIV negative subjects were also recruited. Blood samples were collected for serum analysis of some micronutrients ( $\mathrm{Se}, \mathrm{Cu}$ and $\mathrm{Zn}$ ) and electrolytes ( $\mathrm{Na}, \mathrm{K}$ and $\mathrm{CI}$ ) levels at baseline of the study (pre-HAART) and after six months of therapy (HAART).

\section{Selection of Subjects}

A total of 163 participants were involved in the study, of which 111 were HIV positive (designated as pre-HAART and HAART) and 52 HIV-negative controls. The controls were recruited such that there was no significant difference in age when compared to HIV positive individuals.

\section{Ethical Approval}

Ethical approval for the study was obtained from the Emuoha General Hospital Ethical Committee (EGHEC), Rivers State Ministry of Health, Rivers State, Nigeria.

\section{Eligibility of Subject}

Inclusion Criteria: Only HIV positive patients without any complications such as tuberculosis, pregnancy, hepatitis, hypertension, kidney problem, diabetes and any other ailment that has significant effects on the parameters of interest and healthy HIV negative controls who consented were recruited for this study.

Exclusion Criteria: HIV positive subject and HIV negative subjects with any complication or ailment that has significant effects on the parameters of interest were excluded from the study.

Consent: Informed written consent was obtained from each willing participant and pre-test counseling was instituted in the course of the conduct of this study. The objectives, benefits and procedure for the study was made very clear to the participants and they were assured of the confidentiality and voluntariness associated with the study.

\section{Specimen Collection}

Five (5) milliliter of venous blood samples were collected by veni-puncture without stasis from the Subjects (Test and Controls) and transferred to a clean sterile plain bottle to yield serum for micronutrients (copper, zinc and selenium) and electrolytes (sodium, potassium, chloride and bicarbonate) determination. The blood specimens were allowed to stand for about an hour to clot and for retraction and then centrifuged at 3,500rpm for 10 minutes at room temperature. The serum was separated and stores at $-200 \mathrm{C}$ until time of analysis.

\section{Sample Analyses}

HIV Testing: HIV testing for all patients was performed using the current National algorithm for HIV sero-diagnosis. This involved the use of 3 rapid diagnostic kits, following their manufacturer's instructions. Briefly, each patient's serum was screened for the presence of HIV antibodies using Alere Determine TM HIV-1/2 Ag/ Ab Combo Rapid Tests Kits (Abbot Rapid Diagnostics, California, USA) and Uni-GoldTM Recombigen $®$ HIV-1/2 (Trinity Biotech Plc, Wicklow, Ireland). When both kits showed positivity, the patient was regarded as positive for HIV infection and vice versa. However, when test results were discordant, a third kit, which is the Tie breaker, Chembio HIV 1/2 STAT-PAK® Rapid Test Kit (Chembio Diagnostic systems, New York, USA) was used. The HIV sero-status of the patient was taken as the result of either of the first two kits that agree with that of the third kit $[2,46]$. In case of a positive test, patients were referred to the ART clinic in the same facility for enrolment in HIV care and consideration of ART initiation.

Trace Elements Analysis: Serum Zinc, Copper and Selenium concentrations were determined using Atomic Adsorption Spectrophotometry (Buck Scientific, 210, Atomic Absorption Spectrophotometer, Connecticut, USA) as previously described by Arinola et al. [47].

Analysis of Vitamins: Serum vitamins were determined using the Highly Performance Liquid Chromatography (HPLC). Vitamins $A$ and $\mathrm{E}$ being fat soluble vitamins were determined as described by Comstock et al. [48], while vitamins C, a water soluble vitamin was determine as described by McCoy et al. [49].

Estimation of Serum Electrolytes Levels: Serum electrolytes levels were analyzed by Potentiometric method using an automated Chemistry Analyzer (Model 3000, Buck Scientific Corporation, Connecticut, USA).

\section{Data Analysis}

Data obtained were analyzed using Statistical Packages for Social Sciences - Version 20.0 (SPSS-20.0). Results generated were expressed as mean+SD and a p-value of $<0.05$ was considered statistically significant. The significance difference among the groups was assessed by repeated-measures analysis of variance (ANOVA). 


\section{Results}

Table 1: Socio-Demographic Characteristics of the Study Participants.

\begin{tabular}{|c|c|c|c|c|}
\hline Variable & Categories & HIV-Positive N (\%) & Controls N (\%) & Total N (\%) \\
\hline \multirow{3}{*}{ Gender } & Male & $25(22.5)$ & $11(21.2)$ & $36(22.1)$ \\
\hline & Female & $86(77.5)$ & $41(78.8)$ & $127(77.9)$ \\
\hline & Total & $111(68.1)$ & $52(31.9)$ & $163(100)$ \\
\hline \multirow{5}{*}{ Age } & 11-20Yrs & $20(18.0)$ & $12(23.0)$ & $32(19.6)$ \\
\hline & 21-30Yrs & $36(32.4)$ & 17 (32.7) & $53(32.5)$ \\
\hline & $31-40$ Yrs & $31(28.0)$ & $12(23.1)$ & $43(26.4)$ \\
\hline & 41-60Yrs & $24(21.6)$ & $11(21.2)$ & $35(21.5)$ \\
\hline & Total & 111 (68.1) & $52(31.9)$ & $163(100)$ \\
\hline \multirow{3}{*}{ Marital Status } & Married & $41(37.0)$ & $23(44.2)$ & $64(39.3)$ \\
\hline & Single & $70(63.1)$ & $29(55.8)$ & $99(60.7)$ \\
\hline & Total & 111 (68.1) & 52 (31.9) & $163(100)$ \\
\hline \multirow{6}{*}{ Occupation } & Civil Servant & $2(1.8)$ & $2(3.8)$ & $4(2.4)$ \\
\hline & Farming & $23(20.7)$ & $8(15.4)$ & $31(19.0)$ \\
\hline & Trading & $47(42.3)$ & $26(50.0)$ & $73(44.8)$ \\
\hline & Artisans & $5(4.5)$ & $13(25.0)$ & $18(11.0)$ \\
\hline & Unemployed & $34(30.6)$ & $3(5.8)$ & $37(22.1)$ \\
\hline & Total & $111(68.1)$ & $52(31.9)$ & $163(100)$ \\
\hline \multirow{5}{*}{ Education } & None & $28(25.2)$ & $7(13.5)$ & $35(21.5)$ \\
\hline & Primary & $48(43.2)$ & $22(42.3)$ & $70(43.0)$ \\
\hline & Secondary & $34(30.6)$ & $21(40.4)$ & $55(33.7)$ \\
\hline & Tertiary & $1(0.90)$ & $2(3.8)$ & $3(1.8)$ \\
\hline & Total & $111(68.1)$ & $52(31.9)$ & $163(100)$ \\
\hline
\end{tabular}

The socio-demographic profile of the study participants is presented in Table 1. Out of the 163 cohorts, 111 (68.1\%) were HIV positive, while 52 (31.9\%) were HIV negative. 36 (22.1\%) were males, while 127 (77.9\%) were females. 32 (19.6\%) of the participants were within the age range of 11-20years, 53 (32.5\%) within 21-30years, 43 (26.4\%) within 31-40years, while 35
(21.5\%) were within 41-60years. 64 (39.3\%) were married, while 99 (60.7\%) were singles. 4 (2.4\%) were civil servants, 31 (19.0\%) were farmers, $73(44.8 \%)$ were traders, 18 (11.0\%) were artisans, while 37 (22.1\%) were unemployed. 35 (21.5\%) had no formal education, $70(43.0 \%)$ had primary school education, $55(33.7 \%)$ had secondary education, while $3(1.8 \%)$ had tertiary education.

Table 2: Mean \pm SD Pre-HAART and HAART Serum micronutrients levels of HIV Positive Patients in comparison with the controls.

\begin{tabular}{|c|c|c|c|c|}
\hline Parameters & $\begin{array}{c}\text { Pre-HAART HIV } \\
\text { Positive (N=111) }\end{array}$ & $\begin{array}{c}\text { HAART } \\
\text { Positive (N=111) }\end{array}$ & $\begin{array}{c}\text { Controls } \\
\text { Negative (N=52) }\end{array}$ & F-Value \\
\hline Vitamin A ( $\mu \mathrm{g} / \mathrm{dl})$ & $6.32 \pm 1.11$ & $8.02 \pm 0.70$ & $9.70 \pm 0.93$ & 334.709 \\
\hline Vitamin C (mg/dl) & $0.75 \pm 0.09$ & $1.21 \pm 0.42$ & $1.73 \pm 0.16$ & 192.521 \\
\hline Vitamin E (mg/dl) & $0.35 \pm 0.04$ & $0.41 \pm 0.02$ & $0.67 \pm 0.09$ & 13.116 \\
\hline Zinc $(\mu \mathrm{g} / \mathrm{dl})$ & $76.20 \pm 9.16$ & $89.20 \pm 4.73$ & $98.48 \pm 3.34$ & 228.948 \\
\hline Copper $(\mu \mathrm{g} / \mathrm{dl})$ & $35.12 \pm 2.82$ & $31.66 \pm 2.33$ & $26.43 \pm 3.34$ & 0.000 \\
\hline Selenium $(\mu \mathrm{g} / \mathrm{dl})$ & $23.30 \pm 5.91$ & $44.42 \pm 5.23$ & $55.17 \pm 6.02$ & 0.000 \\
\hline
\end{tabular}

$P$ values $<0.05$ are considered statistically significant.

The mean \pm SD Pre-HAART and HAART serum levels of some micronutrients (vitamin A, vitamin C, Vitamin E, zinc copper and selenium) of HIV positive test Subjects in comparison with the Controls (HIV-negative) is presented in Table 2. The mean \pm SD HAART serum Vitamin A $(8.02 \pm 0.70 \mu \mathrm{g} / \mathrm{dl})$, Vitamin C $(1.21 \pm 0.42 \mathrm{mg} / \mathrm{dl})$ and Vitamin E $(0.41 \pm 0.02 \mathrm{mg} / \mathrm{dl})$ serum levels of the HIV positive test subjects were lower than the controls $(9.70 \pm 0.93 \mu \mathrm{g} / \mathrm{dl}, 1.73 \pm 0.16 \mathrm{mg} / \mathrm{dl}$ and $0.67 \pm 0.09 \mathrm{mg} /$ 
$\mathrm{dl}$, respectively), but significantly higher $(\mathrm{P}<0.05)$ than the mean \pm SD Pre-HAART values $(6.32 \pm 1.11 \mathrm{ug} / \mathrm{dl}, 0.75 \pm 0.09 \mathrm{mg} / \mathrm{dl}$ and $0.35 \pm 0.04 \mathrm{mg} / \mathrm{dl}$, respectively).

Similarly, the mean \pm SD HAART serum Zinc $(89.20 \pm 4.73 \mu \mathrm{g} / \mathrm{dl})$ and Selenium $(44.42 \pm 5.23 \mu \mathrm{g} / \mathrm{dl})$ serum levels of the HIV positive test Subjects were lower than the controls $(98.48 \pm 3.34 \mu \mathrm{g} / \mathrm{dl}$ and $55.17 \pm 6.02 \mu \mathrm{g} / \mathrm{dl}$, respectively), but significantly higher $(\mathrm{P}<0.05)$ than the Pre-HAART values $(76.20 \pm 9.16 \mu \mathrm{g} / \mathrm{dl}$ and $23.30 \pm 5.91 \mu \mathrm{g} /$ $\mathrm{dl}$, respectively). On the other hand, the mean \pm SD serum copper levels of the HAART HIV-positive subjects $(31.66 \pm 2.33 \mu \mathrm{g} / \mathrm{dl})$ were higher than the controls $(26.43 \pm 3.34 \mu \mathrm{g} / \mathrm{dl})$, but significantly lower
$(\mathrm{P}<0.05)$ than that of the pre-HAART $(35.12 \pm 2.82 \mu \mathrm{g} / \mathrm{dl})$.

Furthermore, the Mean \pm SD Pre-HAART and HAART serum electrolytes (potassium, sodium and chloride) levels of HIV positive Patients in comparison with the controls (HIV negative) is presented in Table 3. Our results show that the mean \pm SD HAART serum Potassium $(3.92 \pm 0.43 \mathrm{mmol} / \mathrm{L})$ and Sodium $(134.50 \pm 3.27 \mathrm{mmol} / \mathrm{L})$ serum levels of the HIV positive Patients were lower than the controls $(4.07 \pm 0.57 \mathrm{mmol} / \mathrm{L}$ and $137.46 \pm 3.35 \mathrm{mmol} / \mathrm{L}$, respectively), but significantly higher $(\mathrm{P}<0.05)$ than the mean \pm SD Pre-HAART values $(3.29 \pm 0.33 \mathrm{mmol} / \mathrm{L}$ and $132.61 \pm 2.46 \mathrm{mmol} / \mathrm{L}$, respectively).

Table 3: Mean \pm SD Pre-HAART and HAART serum electrolytes levels of HIV positive Patients in comparison with the controls.

\begin{tabular}{|c|c|c|c|c|c|}
\hline Parameters & $\begin{array}{c}\text { Pre-HAART HIV } \\
\text { Positive (N=11) }\end{array}$ & $\begin{array}{c}\text { HAART HIV Positive } \\
(\mathrm{N}=111)\end{array}$ & $\begin{array}{c}\text { Controls HIV Negative } \\
(\mathrm{N}=52)\end{array}$ & F-value & P-value \\
\hline Potassium (mmol/L) & $3.29 \pm 0.33$ & $3.92 \pm 0.43$ & $4.07 \pm 0.57$ & 85.678 & $0.000^{*}$ \\
\hline Sodium (mmol/L) & $132.61 \pm 2.46$ & $134.50 \pm 3.27$ & $137.46 \pm 3.35$ & 88.169 & $0.000^{*}$ \\
\hline Chloride (mmol/L) & $98.92 \pm 5.65$ & $99.59 \pm 6.53$ & $100.42 \pm 6.28$ & 4.286 & 0.146 \\
\hline
\end{tabular}

P values $<0.05$ are considered statistically significant.

On the other hand, there was no significant difference $(\mathrm{P}>0.05)$ between the mean \pm SD Pre-HAART $(98.92 \pm 5.65 \mathrm{mmol} / \mathrm{L})$ and HAART (99.59 $\pm 6.53 \mathrm{mmol} / \mathrm{L})$ serum chloride levels of HIV-positive Patients and the Controls $(100.42 \pm 6.28 \mathrm{mmol} / \mathrm{L})$.

Table 4 shows gender distribution of Pre-HAART serum levels of some micronutrients and electrolytes of HIV positive Patients. There were no significant differences between the males' mean \pm SD Pre-HAART serum vitamin A $(5.97 \pm 0.96 \mu \mathrm{g} /$ dl), vitamin C $(0.71 \pm 0.12 \mathrm{mg} / \mathrm{dl})$, vitamin $\mathrm{E}(0.30 \pm 0.05 \mathrm{mg} / \mathrm{dl})$, zinc $(74.56 \pm 8.11 \mu \mathrm{d} / \mathrm{dl})$, copper $(34.70 \pm 3.17 \mu \mathrm{g} / \mathrm{dl})$, selenium $(22.23 \pm 5.57 \mu \mathrm{g} / \mathrm{dl}), \quad$ Potassium $\quad(3.17 \pm 0.16 \mathrm{mmol} / \mathrm{L}), \quad$ Sodium $(132.88 \pm 2.42 \mathrm{mmol} / \mathrm{L})$ and Chloride $(98.16 \pm 5.54 \mathrm{mmol} / \mathrm{L})$ serum levels and that of their HIV positive female counterparts: $6.43 \pm 1.14 \mu \mathrm{g} / \mathrm{dl}, 0.76 \pm 0.21 \mathrm{mg} / \mathrm{dl}, 0.30 \pm 0.05 \mathrm{mg} / \mathrm{dl}, 76.67 \pm 9.44 \mu \mathrm{d} /$ $\mathrm{dl}, \quad 35.26 \pm 2.72 \mu \mathrm{g} / \mathrm{dl}, \quad 23.61 \pm 6.00 \mu \mathrm{g} / \mathrm{dl}, \quad 3.33 \pm 2.49 \mathrm{mmol} / \mathrm{L}$, $132.88 \pm 2.49 \mathrm{mmol} / \mathrm{L}$ and $99.14 \pm 5.69 \mathrm{mmol} / \mathrm{L}$, respectively.

Table 4: Gender distribution of Mean \pm SD Pre-HAART serum levels of some micronutrients and electrolytes of HIV positive Patients.

\begin{tabular}{|c|c|c|c|c|}
\hline Parameters & $\begin{array}{l}\text { Pre-HAART HIV Positive } \\
\text { Males }(\mathrm{N}=25)\end{array}$ & $\begin{array}{l}\text { Pre-HAART HIV Positive } \\
\text { Females }(\mathrm{N}=86)\end{array}$ & $t$-value & $p$-value \\
\hline Vitamin A ( $\mu \mathrm{g} / \mathrm{dl})$ & $5.97 \pm 0.96$ & $6.43 \pm 1.14$ & 1.834 & 0.069 \\
\hline Vitamin C (mg/dl) & $0.71 \pm 0.12$ & $0.76 \pm 0.21$ & 1.174 & 0.243 \\
\hline Vitamin E (mg/dl) & $0.30 \pm 0.05$ & $0.30 \pm 0.05$ & 0.001 & 0.999 \\
\hline $\operatorname{Zinc}(\mu \mathrm{g} / \mathrm{dl})$ & $74.56 \pm 8.11$ & $76.67 \pm 9.44$ & 1.015 & 0.312 \\
\hline Copper $(\mu \mathrm{g} / \mathrm{dl})$ & $34.70 \pm 3.17$ & $35.26 \pm 2.72$ & 0.847 & 0.399 \\
\hline Selenium ( $\mu \mathrm{g} / \mathrm{dl})$ & $22.23 \pm 5.57$ & $23.61 \pm 6.00$ & 1.025 & 0.308 \\
\hline Potassium (mmol/L) & $3.17 \pm 0.16$ & $3.33 \pm 2.49$ & 0.616 & 0.539 \\
\hline Sodium (mmol/L) & $132.88 \pm 2.42$ & $132.88 \pm 2.49$ & 0.616 & 0.539 \\
\hline Chloride (mmol/L) & $98.16 \pm 5.54$ & $99.14 \pm 5.69$ & 0.761 & 0.448 \\
\hline
\end{tabular}

$P$ values $<0.05$ are considered statistically significant.

In addition, Table 5 shows gender distribution of Mean \pm SD HAART serum levels of some micronutrients and electrolytes of HIV positive Patients. There were no significant differences between the males' mean \pm SD HAART serum vitamin A $(9.21 \pm 0.77 \mu \mathrm{g} / \mathrm{dl})$, vitamin $\mathrm{E}(0.66 \pm 0.91 \mathrm{mg} / \mathrm{dl})$, copper $(31.12 \pm 2.47 \mu \mathrm{g} / \mathrm{dl})$, selenium $(44.46 \pm 4.09 \mu \mathrm{g} / \mathrm{dl}), \quad$ Potassium $(3.98 \pm 0.36 \mathrm{mmol} / \mathrm{L}), \quad$ Sodium $(137.00 \pm 2.97 \mathrm{mmol} / \mathrm{L})$ and Chloride $(101.68 \pm 6.72 \mathrm{mmol} / \mathrm{L})$ serum levels and that of their HIV positive female counterparts:
$8.97 \pm 0.67 \mu \mathrm{g} / \mathrm{dl}, \quad 0.71 \pm 0.82 \mathrm{mg} / \mathrm{dl}, \quad 31.82 \pm 2.29 \mu \mathrm{d} / \mathrm{dl}$, $44.41 \pm 5.55 \mu \mathrm{g} / \mathrm{dl}, \quad 3.91 \pm 0.45 \mathrm{mmol} / \mathrm{L}, \quad 137.65 \pm 3.36 \mathrm{mmol} / \mathrm{L}$ and $101.57 \pm 5.52 \mathrm{mmol} / \mathrm{L}$, respectively. On one hand, while the HIV positive males' mean \pm SD HAART serum vitamin $C$ serum level $(1.46 \pm 0.36 \mathrm{mg} / \mathrm{dl})$ was significantly higher $(\mathrm{P}<0.05)$ than that of their female counterparts $(1.14 \pm 0.41 \mathrm{mg} / \mathrm{dl})$, on the other hand, their mean \pm SD HAART serum zinc level $(89.42 \pm 2.45 \mu \mathrm{g} / \mathrm{dl})$ was significantly lower than that of the females $(94.71 \pm 4.71 \mu \mathrm{g} / \mathrm{dl})$. 
Table 5: Gender distribution of HAART serum levels of some micronutrients and electrolytes of HIV positive subjects.

\begin{tabular}{|c|c|c|c|c|}
\hline Parameters & $\begin{array}{l}\text { HAART HIV Positive Males } \\
\qquad(\mathrm{N}=25)\end{array}$ & $\begin{array}{l}\text { HAART HIV Positive } \\
\text { Females }(\mathrm{N}=86)\end{array}$ & t-value & P-value \\
\hline Vitamin A ( $\mu \mathrm{g} / \mathrm{dl})$ & $9.21 \pm 0.77$ & $8.97 \pm 0.67$ & 1.479 & 0.142 \\
\hline Vitamin C (mg/dl) & $1.46 \pm 0.36$ & $1.14 \pm 0.41$ & 3.545 & $0.001^{*}$ \\
\hline Vitamin E (mg/dl) & $0.66 \pm 0.91$ & $0.71 \pm 0.82$ & 0.247 & 0.805 \\
\hline $\operatorname{Zinc}(\mu \mathrm{g} / \mathrm{dl})$ & $89.42 \pm 2.45$ & $94.71 \pm 4.71$ & 2.171 & $0.032^{*}$ \\
\hline Copper $(\mu \mathrm{g} / \mathrm{dl})$ & $31.12 \pm 2.47$ & $31.82 \pm 2.29$ & 1.348 & 0.181 \\
\hline Selenium ( $\mu \mathrm{g} / \mathrm{dl})$ & $44.46 \pm 4.09$ & $44.41 \pm 5.55$ & 0.040 & 0.968 \\
\hline Potassium (mmol/L) & $3.98 \pm 0.36$ & $3.91 \pm 0.45$ & 0.731 & 0.466 \\
\hline Sodium (mmol/L) & $137.00 \pm 2.97$ & $137.65 \pm 3.36$ & 0.875 & 0.384 \\
\hline Chloride (mmol/L) & $101.68 \pm 6.72$ & $101.57 \pm 5.52$ & 0.074 & 0.942 \\
\hline
\end{tabular}

$P$ values $<0.05$ are considered statistically significant

\section{Discussion}

This present study assessed the effects of HAART initiation on some serum micronutrients and electrolytes serum levels in HIV positive Patients attending Emuoha General Hospital, Emuoha Local Government Area, Rivers State, Southern Nigeria, six-months post-therapy.

The outcome of this study shows that micronutrients and electrolytes deficiencies exist in HIV infected individuals in the absence of HAART. The lower Pre-HAART vitamins and mineral elements serum levels as seen in this present study is in agreement with the findings of other previous studies including those of Akinola et al. [21], Anyabolu et al. [37], Arinola et al. [47], Graham et al. [50], Constans et al. [51], Coutsoudis et al. [52], Stephensen et al. [53], Lawal et al. [54] and Forrester and Sztam [55], who all reported lower levels in HIV infected Patients; compared with the controls. The mean \pm SD Pre-HAART Zinc and Selenium levels of the HIV infected Subjects were found to be significantly lower $(\mathrm{P}<0.05)$ than the controls. This is consistent with the findings of Eley et al. [56], Bobat et al. [57] and Ogunro et al. [58]. The reduction in Selenium level may be caused by several factors such as latent state induced by the virus, malabsorption, altered metabolism, gut infection, altered gut barrier function and the hypermetabolic state [59-61]. It has also been suggested that a possible cause of selenium depletion among HIV positive Subjects is the utilization of selenium by HIV-l virus to produce its own selenoenzymes [62-64].

Low or deficient serum concentrations of micronutrients in HIV infected patients has been individually associated with either low CD+T-cell counts, advanced HIV-related diseases, increased disease progression or mortality [13,21,30,40,65-67]. Possible mechanisms as earlier posited include increased intracellular oxidative stress which is responsible for the production of reactive oxygen species (ROS) such as superoxide anion, hydroxyl radical, and hydrogen peroxide. Excessive production of ROS has been associated with increased stimulation of HIV replication, increased pro-oxidant effect of tumor necrosis factor (TNF) and accelerated development of Immunodeficiency contributing to the increased morbidity, more rapid disease progression, and the higher mortality seen in HIVinfected patients with micronutrient deficiencies $[17,19,42,44]$.
In addition, poor dietary intakes, poor absorption and diarrhea which is common in HIV infection, may also have contributed to the reduced levels of micronutrients and electrolytes in the HIV subjects [15]. Also, the recycling mechanism of biologically active vitamin $\mathrm{E}$ through ascorbate has been reported to be impaired in HIV patients [54,68].

On the other hand, the mean \pm SD serum copper levels of the pre-HAART HIV infected Patients $(35.12 \pm 2.82 \mu \mathrm{g} / \mathrm{dl})$ in this study was found to be significantly higher $(\mathrm{P}<0.05)$ than that of the controls $(26.43 \pm 3.34 \mu \mathrm{g} / \mathrm{dl})$. This is in accordance with the findings of previous studies done by Lawal et al. [54] and Nwegbu et al. [69] who both reported a significant increase in the mean plasma copper concentration of HIV infected Subjects when compared with control group. Copper as a compound is required for immune complex formation, blood and coagulation factors formation. In fact, it is a major micronutrient required by the body in HIV infection [32].

With regard to their serum electrolytes levels, the mean \pm SD Pre-HAART serum Potassium and Sodium serum levels of the HIV infected were significantly $(\mathrm{P}<0.05)$ lower than the controls. This agrees with the works of Ross, Klothman [70] and Eshiet et al. [71] who both observed that HIV infection at different clinical stages may present fluid electrolytes and acid-base abnormalities, acute renal-failure and glomerulopathy. The observed lower levels of plasma K+ in the HIV infected Patients Pre-HAART in this study may be attributed to the dilution of the extracellular space, movement of $\mathrm{K}+$ into cells or loss from the body or kidney as earlier reported by Ziegler [72].

Furthermore, although lower micronutrients and electrolytes levels were observed among HIV infected patient's Pre-HAART in this present study, these deficiencies were however corrected with the initiation of HAART. This was evident by a significant higher $(\mathrm{P}<0.05)$ mean \pm SD HAART serum Vitamin A, Vitamin C, Vitamin E, Zinc, Selenium, Potassium and Sodium serum levels (except Copper and Chloride) of the HIV positive Patients in comparison with the mean \pm SD Pre-HAART values. This observation agrees with that of Akinola et al. [21], Arinola et al. [47] and Sundaram et al. [73] who observed a significant increase in zinc and that of Akinboro et al. [22] and Look et al. [74] who observed a significant increase 
in serum selenium serum level following initiation of HAART. But, it however disagrees with the report of Akinola et al. [21] who observe no significant $(\mathrm{P}>0.05)$ difference between the mean serum levels of Selenium and Copper in HAART patients compared to Pre-HAART patients.

Furthermore, the mean \pm SD HAART serum zinc and selenium levels were observed to be lower than the control in this study, but the serum copper level was found to be higher. This contradicts the work of Batterham et al. [75] who observed no significant difference in serum selenium between those on HAART and the control group. And it also opposed the work of Akinola et al. [21], who observed that Patients on HAART had significant $(\mathrm{P}<0.05)$ higher levels of zinc, but lower level of copper and selenium levels compared to control subjects. High zinc level in these patients was thought to be beneficial since zinc could be both an inhibitor of reverse transcriptase and activator of the 'tat protein'.

Rousseau et al. [76] in a work titled, "Influence of highly active antiretroviral therapy on micronutrient profiles in HIVinfected patients", observed significant decrease in the percentage of persons with selenium deficiency (from $77 \%$ to $10 \%$ ) and copper overload (from $98 \%$ to $43 \%$ ) after HAART initiation. Their findings show that selenium, copper and zinc levels were neither significantly improved after HAART initiation nor higher in those receiving HAART at follow-up. They therefore conclude that HAART may reduce selenium deficiency and not necessarily increase its level.

On the other hand, there was no significant difference $(\mathrm{P}>0.05)$ between the mean \pm SD Pre-HAART and HAART serum chloride levels of HIV-positive Patients when compared to the Controls. The reason for this observation is not well understood and would require further investigation. Howbeit, lower plasma chloride concentration has been linked to heavy sweating, vomiting, diarrhea, dehydration, adrenal and kidney diseases as reported by Kleyman et al. [77].

We recognized some limitations in this study. Firstly, viral load assessment was not done; hence it was difficult to characterize the patients who failed to respond to HAART. Secondly, this is a crosssectional analysis and a finding of association does not necessarily mean causation. Thirdly, we recognized that serum concentrations may not be the best measure of total body stores for micronutrients since serum levels are tightly regulated across a range of dietary intake. Large randomized placebo-controlled trials should be conducted in HIV-positive persons receiving HAART to determine effects on clinical and laboratory rather than just laboratory HIVrelated outcomes.

\section{Conclusion}

The outcome of this study confirms that micronutrients and electrolytes deficiencies exist in HIV infection which were corrected following HAART initiation. This further strengthened earlier works that posited that HAART can improves life expectancy through repletion of micronutrients and electrolytes levels with a normal kidney function. The decrease in micronutrients that accompanies HIV infection suggests a potentially important role of nutritional supplementation and good nutrition in the proper management of HIV/AIDS. We therefore recommend that HIV infected Patients should be investigated and treated for micronutrients and electrolytes deficiency, if present, to reduce the morbidity and mortality associated with HIV infection. Close monitoring of patients before and during HAART is very critical to aid in evaluating drug combinations and implementation of dose modifications when necessary. The information obtained in this study will therefore help health workers to emphasize on the use of HAART in their campaign for HIV management and encourage HIV patients in making themselves available to be treated especially at the early stage of infection.

\section{References}

1. Oladeinde BH, Omoregie R, Olley M, Anunibe JA (2011) Prevalence of HIV and anaemia among pregnant women in a rural community of Nigeria. International Journal of Basic and Applied Virology 1(1): 15.

2. Olayanju AO, Afolabi T, Ezigbo ED, Enitan SS, Oluwatayo BO (2018) Assessment of Antiphospholipid Antibodies, CD4 Count and Some Haematological Parameters in HIV Patients attending a Tertiary Health Institution in South-Western Nigeria. International Blood Research \& Review 8(2): 1-14.

3. UNAIDS-Joint United Nations Programme on HIV and AIDS (2016) Fact sheet-latest statistics on the status of the AIDS epidemic.

4. Hogg RS, Yip B, Kully C, Craib KJP, O’Shaughnessy MV, et al. (1999) Improved survival among HIV-infected Patients after initiation of triple drug antiretroviral regimens. CMAJ 160(5): 659-665.

5. Yeni PG, Hammer SM, Carpenter CC, Cooper DA, Fischl MA, et al. (2002) Antiretroviral treatment for adult HIV infection in 2002: Updated recommendations of the International AIDS Society-USA Panel. JAMA 288(2): 222-235.

6. Moore AL, Kirk O, Johnson AM (2003) Virologic, immunologic and clinical response to highly active antiretroviral therapy: The gender issue revisited. J Acquir Immune Defic Syndr 32(4): 452-461.

7. Palella FJ Jr, Baker RK, Moorman AC, Chmiel JS, Wood KC, et al. (2006) Mortality in the highly active antiretrovial therapy era: Changing causes of death and disease in the HIV outpatient study. Journal of Acquired Immune Deficiency Syndrome 43(1): 27-34.

8. Itodo GE, Enitan SS, Samanu VO, Ehiaghe FA, Akele YR, et al. (2015) Effect of highly active antiretroviral therapy (HAART) On CD4+ cell count and liver enzymes in HIV infection at Lokoja, Nigeria. African Journal of Cellular Pathology 4: 34-41.

9. UNAIDS: Joint United Nations Programme on HIV and AIDS (2013) New HIV infections among children have been reduced by $50 \%$ or more in seven countries in sub-Saharan Africa, UN AIDS, Geneva.

10. Akele RY, Olayanju AO, Bala ND, Chollom SC, Enitan SS, Irec J (2015) Haematological parameters in Human Immunodeficiency Virus positive individuals on different HAART regimen. World Journal of Pharmaceutical Research 4(12): 30-42.

11. Moore RD, Keruly JC, Gebo KA, Lucas GM (2005) An improvement in virologic response to highly active antiretroviral therapy in clinical practice from 1996 through 2002. J Acquir Immune Defic Syndr 39(2): 195-198.

12. Drain PK, Kupka R, Mugusi F, Fawzi WW (2007) Micronutrients in HIVpositive persons receiving highly active antiretroviral therapy. The American Journal of Clinical nutrition 85(2): 333-345.

13. Amit M, Habib H, Akhtar H (2009) Correlation of CD4+ T cell count with serum zinc, copper and selenium in HIV positive individuals. Internet J Epidemiol p. 6.

14.Zaneta MP, Annmeyer S, Gardner C (2012) HIV Medications-Food 
Interaction Hand Book, (2 ${ }^{\text {nd }}$ Edn); Indiana University Medical Centre, Indianapolis pp 1-8.

15. Dworkin BM, Wormser GP, Axelrod F, Pierre N, Schwarz E, et al. (1990) Dietary intake in patients with acquired immunodeficiency syndrome (AIDS), patients with AIDS-related complex, and serologically positive human immunodeficiency virus patients: correlations with nutritional status. JPEN J Parenter Enteral Nutr 14(6): 605-609.

16. Fuchs J, Ochsendorf F, Schöfer H, Milbradt R, Rübsamen-Waigmann H (1991) Oxidative imbalance in HIV infected patients. Med Hypotheses 36(1): 60-64.

17. Allard JP, Aghdassi E, Chau J, Salit I, Walmsley S (1998) Oxidative stress and plasma antioxidant micronutrients in humans with HIV infection. Am J Clin Nutr 67(1): 143-147.

18. Allard JP, Aghdassi E, Chau J (1998) Effects of vitamin E and C supplementations on oxidative stress and viral load in HIV-infected subjects. AIDS 12(13): 1653-1659.

19. Das UN, Podama M, Sogner PS (1990) Stimulation of free radical generations in human leucocytes by various agents including tumor necrosis factor is a calmodulin-dependent process. Biochem Biophys Res Commun 167(3): 1030-1036.

20. Berger, MM, Shenkin A (2006) Update on clinical micronutrient supplementation studies in the critically ill. Curr Opin Clin Nutr Metab Care 9(6): 711-716.

21. Akinola FF, Akinjinmi AA, Oguntibeju OO (2012) Effect of Combined Antiretroviral Therapy on Selected Trace Elements and CD4 T-cell Count in HIV-Positive Persons in an African Setting. Journal of AIDS \& Clinical Research 3: 185.

22. Akinboro AO, Onayemi O, Ayodele OE, Mejiuni AD, Atiba AS (2013) The impacts of first line highly active antiretroviral therapy on serum selenium, CD4 count and body mass index: A cross-sectional and short prospective study. Pan African Medical Journal 15: 97.

23. Attah RA, Attah CJ, Muhammed MJ (2016) Effect of Micronutrients on HIV infected Patients Receiving Highly Active Antiretroviral Therapy and its Implication on markers of Renal Disease. The South Asian Journal of Medicine 1(2): 22-28.

24. Evans P, Halliwell B (2001) Micronutrients: Oxidant/antioxidant status. Br J Nutr 85(2): S67-S74.

25. Singh M (2004) Role of micronutrients for physical growth and mental development. Indian J Pediatr 71(1): 59-62.

26. Fledler JL, Macdonald B (2009) A strategic approach to the unfinished fortification programs in 48 countries. Food and Nutr Bull 30(4): 283311.

27. Eipper B, Milgram SL, Husten EJ, Yun H, Mains RE (1993) Peptidylglycine alpha amidiating monooxygenae: A multifunctional protein with catalytic, processing, and routing domains. Prot Sci 2(4): 489-497.

28. McLaren DS, Loveridge N, Duthie GG, Bolton-Smith C (1993) Fat Soluble Vitamin In: Human nutrition and dietetics. Garrow JS, James WPT, (eds.); London, Churchill Livingstone Press, pp. 208-238.

29. Berger MM (2003) Key vitamins and trace elements in the critically ill. Nestlke Nutr Workshop Ser Clin Perform Programme 8: 99-111.

30. Allavena C, Dousset B, May T, Dubois F, Canton P, et al. (1995) Relationship of trace element, immunological markers, and HIV1 infection progression. Biol Trace Elem Res 47(1-3): 133-138.

31. Bogden JD, Kemp FW, Han S, Li W, Bruening K, et al. (2000) Status of selected nutrients and progression of human immunodeficiency virus type 1 infection. Am J Clin Nutr 72(3): 809-815.

32. Percival SS (1998) Copper and immunity. Am J Clin Nutr 67: 1064S-1068S.
33. Fraker PJ, King LE, Laakko T, Vollmer TL (2000) The dynamic link between the integrity of the immune system and zinc status. J Nutr 130 : 1399S-1406S.

34. Ferencík M, Ebringer L (2003) Modulatory effects of selenium and zinc on the immune system. Folia Microbiol 48(3): 417-426.

35. Burtis CA, Bruns DE, Ashwood ER (2017) Electrolytes. Burtis CA, Bruns DE, Ashwood ER (eds.) In: Tietz Fundamentals of Clinical Chemistry and Molecular Diagnostics ( $8^{\text {th }}$ Edn). Elsevier.

36. Cheesbrough M (2006) Measurement of Sodium and Potassium in Serum or Plasma. In: Cheesbrough M (edn.). District Laboratory Practice in Topical Countries, Part 1. Cambridge University Press, Cape Town, South Africa pp. 364-369.

37. Anyabolu HC, Adejuyige E, Adeodu O (2014) Serum Micronutrients of HAART-Naïve, HIV infected Children in South Western Nigeria: A Case Controlled Study. AIDS Research and Treatment, p. 8.

38. Owiredu W, Quaye L, Amidu N, Addai-Mensah O (2011) Prevalence of anaemia and immunological markers among Ghanaian HAART-naïve HIV-patients and those on HAART. Afr Health Sci 11(1): 2-15.

39. Onodugo OD, Chukwuka C, Onyedum C, Ejim E, Mbah A, et al. (2013) Baseline Renal Function among Antiretroviral Therapy, HIV-infected Patients in South East Nigeria. J Int Assoc Provid AIDS Care.

40. Tang AM, Graham NM, Kirby AJ, McCall LD, Willett WC, et al. (1993) Dietary micronutrient intake and risk of progression to acquired immunodeficiency syndrome (AIDS) in human immunodeficiency virus type 1 (HIV-1)-infected homosexual men. Am J Epidemiol 138(11): 937951.

41. Cheesbrough M (2006) Human Immunodeficiency Virus. In: Cheesbrough M (eds.). District Laboratory Practice in Topical Countries, Part 2. Cambridge University Press, Cape Town, South Africa. pp. 253 265.

42. Schwartz KB (1996) Oxidative stress during viral infection: A review. Free Radic Bio Med 21(5): 641-649.

43. Oguntibeju 00, van den Heever WMJ, van Schalkwyk FE (2007) The interrelationship between nutrition and the immune system I HIV infection: A Review. Pakistan Journal of Biological Sciences 10(24): 4327-4338.

44. Mandas A, Lorio EL, Congiu MG, Balestrieri C, Mereu A, et al. (2009) Oxidative imbalance in HIV-1 infected patients treated with antiretroviral therapy. J Biomed \& Biotech 7: 1-7.

45. (2006) Rivers Population Statistics. City Population.

46. Digban AK, Osula I, Adesina EB, Aghatise K, Enitan SS (2017) Assessment of CD4 Count and Some Haematological Parameters of HIV Positive Patients Co-infected with Hepatitis B Virus in Osun State, Nigeria. International Blood Research \& Reviews 7(4): 1-13.

47. Arinola OG, Adedapo KS, Kehinde AO, Olaniyi JA, Akiibinu MO (2004) Acute phase proteins, trace elements in asymptomatic human immunodeficiency virus infection in Nigerians. Afr J Med Med Sci 33(4): 317-322.

48. Comstock GW, Alberg AJ, Helzlsouer KJ (1993) Reported effects of long-term freezer storage on concentrations of retinol, $\beta$-carotene, and $\alpha$-tocopherol in serum or plasma summarized. Clin Chem 39(6): 10751078.

49. McCoy LF, Bowen MB, Xu M, Chen H, Schleicher RL (2005) Improved HPLC Assay for Measuring Serum Vitamin C with 1-Methyluric Acid used as an Electrochemically Active Internal Standard. Clinical Chemistry 51(6): 1-3.

50. Graham NM, Sorensen D, Odaka N, Brookmeyer R, Chan D, et al. (1991) Relationship of serum copper and zinc levels to HIV-1 seropositivity and progression to AIDS. J Acquir Immune Defic Syndr 4(10): 976-980.

51. Constans J, Peuchant E, Pellegrin JL, Sergeant C, Hamon C, et al. (1995) 
Fatty acids and plasma antioxidants in HIV-positive patients: correlation with nutritional and immunological status. Clin Biochem 28(4): 421426.

52. Coutsoudis A, Bobat RA, Coovadia HM, Kuhn L, Tsai WY, et al. (1995) The effect of vitamin A supplementation on the morbidity of children born to HIV infected women. Am J Public Health 85(8-1):1076-1080.

53. Stephensen CB, Marquis GS, Jacob RA, Kruzich LA, Douglas SD, et al. (2006) Vitamin $C$ and $E$ in adolescents and young adults with HIV infection. The American Journal of Clinical Nutrition 83(4): 870-879.

54. Lawal S, Bilbis DB, Idowu YS, Mansur L, Chibueze HN (2010) Serum levels of antioxidant vitamins and minerals elements of Human Immunodeficiency Virus Positive Subjects in Sokoto, Nigeria. Annals of African Medicine 9(4): 235-239.

55. Forrester JE, Sztam KA (2011) Micronutrients in HIV/AIDS: is there evidence to change the WHO 2003 recommendations? Am J Clin Nutr 94(6): 1683S-1689S.

56. Eley BS, Sive AA, Abelse L, Kossew G, Copper G, et al. (2002) Growth and micronutrient disturbance in stable, HIV-infected children in Cape Town. Annals of Tropical Paediatrics 22(1): 19-23.

57. Bobat R, Coovadia H, Stephen C (2005) Safety and efficacy of zinc supplementation for children with HIV-1 infection in South Africa: A randomized double-blind placebo-controlled trial. The Lancet 366(9500): 1862-1867.

58. Ogunro PS, Ogungbamigbe TO, Elemie PO, Egbewale BE, Adewole TA (2006) Plasma selenium concentration and glutatione peroxidase activity in HIV/AIDS infected patients: A correlation with the disease progression. Nigerian Postgraduate Medical Journal 13(1): 1-5.

59. Grunfeld C, Kotler DP (1992) Pathophysiology of the AIDS wasting syndrome. AIDS Clin Rev, pp. 191-224.

60. Steinhart CR (2001) HIV-associated wasting in the era of HAART: A practice-based approach to diagnosis and treatment. AIDS Read 11: 557-569.

61. Tang AM, Forrester J, Spiegelman D (2002) Weight loss and survival in HIV-positive patients in the era of highly active antiretroviral therapy. J Acquir Immune Defic Syndr 31(2): 230-236.

62. Shisler JL, Senkevich TG, Berry MJ, Moss B (1998) Ultraviolet-induced cell death blocked by a selenoprotein from a human dermatotropic poxvirus. Science 279(5347): 102-105.

63. Xu XM, Carlson BA, Grimm TA (2002) Rhesus monkey simian immunodeficiency virus infection as a model for assessing the role of selenium in AIDS. J Acquir Immune Defic Syndr 31(5): 453-463.
64. Okunade K, Olowoselu OF, Osanyin GE, Olabode SJ, Akanmu SA, et al. (2018) Selenium deficiency and pregnancy outcome I pregnant women with HIV in Lagos, Nigeria. International Journal of Gynecology \& Obstetrics 142(2): 207-213

65. Beach RS, Mantero-Atienza E, Shor-Posner G, Javier JJ, Szapocznik J, et al. (1992) Specific nutrient abnormalities in asymptomatic HIV-1 infection. AIDS 6(7): 701-708.

66. Abrams B, Duncan D, Hertz-Picciotto I (1993) A prospective study of dietary intake and acquired immune deficiency syndrome in HIVseropositive homosexual men. J Acquir Immune Defic Syndr 6(8): 949958.

67. Coodley GO, Coodley MK, Nelson HD, Loveless MO (1993) Micronutrient concentrations in the HIV wasting syndrome. AIDS 7(12): 1595-1600.

68. Tang MA, Graham NH, Semba R, Saah AJ (1997) Association between serum vitamin $A$ and $E$ levels and HIV-1 disease progression. AIDS 11(5): 613-620.

69. Nwegbu MM, Egua MO, Ogwu OS (2015) Comparative study of plasma zinc and selenium levels amongst Human Immunodeficiency Virus (HIV) positive and negative subjects. African Journal of Food Science and Technology 6(8): 253-258.

70. Roos MJ, Klothman PE (2004) HIV-associated nephropathy. Aids 18: 1089-1099.

71. Eshiet EM, Jemikalajah DJ, Okogun GRA (2015) Plasma urea and electrolysis profile in different stages of HIV infection in Ekpoma, Nigeria. African Journal of Cellular Pathology 4: 1-5.

72.Ziegler PD (1996) Clinical diagnosis and treatment. Migration of potassium into cells. J Clin Med 90: 180-200.

73. Sundaram M, Saghayam S, Priya B, Venkatesh KK, Balakrishnan P, et al. (2008) Changes in antioxidant profile among HIV-infected individuals on generic highly active antiretroviral therapy in southern India. Int J Infect Dis 12(6): e61-e66.

74. Look MP, Rockstroch JK, Rao GS, Kreuzer KA (1997) Serum selenium versus subsets and markers of disease progression and inflammatory response in human immunodeficiency virus-1 infection. Biol Trace Elem Res 56(1): 31-41.

75. Batterham M, Gold J, Naidoo D, Lux O, Sadler S, et al. (2001) A preliminary open label dose comparison using an antioxidant regimen to determine the effect on viral load and oxidative stress in men with HIV/AIDS. Eur J Clin Nutr 55(2): 107-114.

76. Rousseau MC, Molines C, Moreau J, Delmont J (2000) Influence of highly active antiretroviral therapy on micronutrient profiles in HIV-infected patients. Ann Nutr Metab 44(5-6): 212-216.

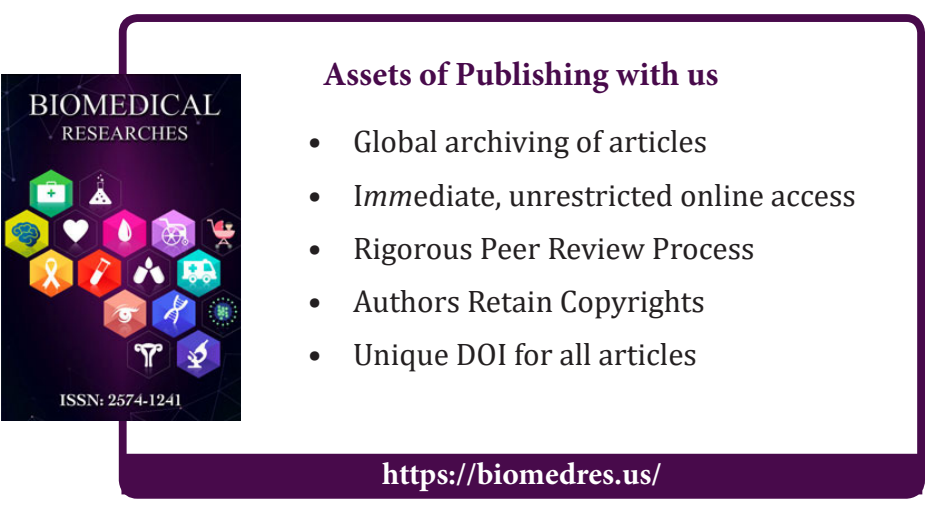

ISSN: 2574-1241

DOI: 10.26717/BJSTR.2018.07.001509

Enitan Seyi Samson. Biomed J Sci \& Tech Res

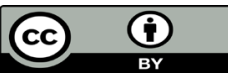

This work is licensed under Creative Commons Attribution 4.0 License

Submission Link: https://biomedres.us/submit-manuscript.php 